\title{
Success Factors of New Product Launch: The Case of iPhone Launch
}

\author{
Gabriela Căpătînă ${ }^{1} \&$ Florin Drăghescu ${ }^{1}$ \\ ${ }^{1}$ The Bucharest University of Economic Studies, Marketing Doctoral School, Romania \\ Correspondence: Gabriela Căpătînă, The Bucharest University of Economic Studies, Marketing Doctoral School, \\ Romania. E-mail: gabriella.capatina@yahoo.com
}

Received: March 20, 2015

Accepted: April 7, 2015

Online Published: April 25, 2015

doi:10.5539/ijef.v7n5p61

URL: http://dx.doi.org/10.5539/ijef.v7n5p61

\begin{abstract}
The continuous globalization and new product launch can represent essential drivers for the company performance. For many years has been conducted conceptual and empirical research in order to identity the success factors for new product launch. Therefore, the purpose of this paper is to identify and analyze the critical success factors for launching a new product using a marketing approach. The contribution to the science of this article is to create an understanding framework related to the factors that have an impact on the success of a new product launch; it could help companies in planning the new products launch. This paper followed a case-study methodology-the iPhone launch case. After iPhone was successfully launched, millions of iPhones was sold, turned it in one of the most popular mobile phone ever launched. Considering that Apple is now the leader on smartphone market, overtaking Samsung in the fourth quarter of 2014, the purpose of this case study is to explain how a company as Apple can enter in a saturated market, have success, and after eight years became the leader market. In order to involve all crucial drivers of product success, we attempted to summarize the findings considering three essential levels-consumers, company, and environmental. Regarding the case study conclusion it can be said that iPhone changed the way that consumers interact with the mobile phones; it built a connection with the consumer and influenced their behavior regarding the information access and digital lifestyle.
\end{abstract}

Keywords: factors, globalization, iPhone, launch, new products, success

\section{Introduction}

In the age of globalization, companies from entire world face various scenarios. The goal of each company is to increase the revenues through new product launch optimization. New products offer increased sales, profits, and competitive strength for most companies. New products launch could be a mean by which the company creates and sustain competitive advantage for itself in the marketplace. Companies like Sony, Mocrosoft, or Dell continuosly launched new products, and made this activity a crucial part of their marketing strategy (Kotler, 2006).

Almost $70-80 \%$ of new products launched each year fail; therefore companies attempt to find the main drivers which could affect the launch success. Many successful organizations such as Apple or JVC owe their fortune to new products that they launched (Cooper, 1993).

The critical success factors from an industry are represented by activities that provide the necessary conditions in order to obtain the success-being its main determinants. The company will be successful if it is really good in carrying out these activities and mediocre in all others. For instance, in the software industry, the key success factors are establishing the effective distribution channels and providing after sales services.

Researchers have responded to the increased managerial concentration on new product launch with a lot of studies that attest the new product success. For instance, Mintel-an research company-states that the phone market will grow from 205.1 million units shipped in 2014 to 255.2 million units in 2019, this grow will slow considerably near the end of the forecast period. The opportunities from the smartphone market are reduced due to the increasing majority of adults that have more advanced devices.

New products launch is the key in succeeding in the technology field and generally, the more a company spends on research, development, and launch the more novelty its creates. Samsung Electronics, the world largest technology company by revenue, has spent $\$ 10.4$ billion for research, development, and launch-the second amount spent for $R \& D$ in the world. 
Globally, the phone market is reaching 30\% of all e-commerce transactions, fashion and luxury items are the most purchaced via phone at $33 \%$, and travel on the second position with $27 \%$. Nowadays, the smartphones market is about buying, not only speeking, browsing, researching or playing-and this is a big opportunity for e-commerce business. To pursuit this idea, Apple have transformed itself into an e-commerce company, it have launched its own mobile payment service-Apple Pay (Wallace, 2014).

This article is structured in three sections: first part is about the necessity to launch new product on the market; second part considering the critical success factors in launching a new product; third part attempts to understand how the success factors has been worked for first iPhone launch. This paper has been conducted by studying theory regarding success factors and new products launch theory. Therefore, the purpose of this article is to identify and analyze the critical success factors for launching a new product using a marketing approach. The contribution to the science of this paper is to create an understanding framework related to the factors that have an impact on the success of a new product launch; it could help companies in planning the new products launch.

\section{New Product Launch}

New product launch should be a common strategy for many companies in order to obtain and maintain the firm success, but these companies could face a problem-launch decisions can often be very costly and risky (Li \& Zhu, 2009). Every firm must develop and launch new products, because they may influence the future of the company. The customers want new products and the competitors will make every effort to provide them (Kotler, 2006).

A lot of theoretical papers have investigated the presence of connections between firm success and new product launch (Klette \& Griliches, 2000; Klette \& Kortum, 2004; Thompson, 2001; Lentz \& Mortensen, 2005). Therefore, the increasing literature that focuses on examming the link between new products launch and firm success confirms the relevance of this topic (Nurmi, 2004; Loof \& Heshmati, 2006; Del Monte \& Papagni, 2003; Yang \& Huang, 2005), but these investigations has focused more on the R\&D intensity and patenting indicators, rather than new products success introduction (Flor \& Oltra, 2004; Becheikh, Landry, \& Armara, 2006).

The product is a multidimensional concept that can be approached in terms of physical, functional, packaging, price, brand, and technology characteristics. New product concept is a widely debated topic with different approaches. One of the first studies on the product is undertaken by the firm Booz Allen \& Hamilton-have been investigated 13,000 new products launched by a number of 700 U.S. companies in the early 80 s (Booz \& Hamilton, 1982).

American researchers have shown that products could be classified into the following six classes according to their novelty for company or novelty for market:

- New-to-the-world products: also known as discontinuous innovation, they are products that are new to the practice and for knowledge this branch.

- New product lines: not represent a real novelty for the market, but they are new for the company.

- Additions to existing product lines: are new products for company but they are part of a product line that has already been assimilated by the company.

- Improvements or revisions of existing products: provide value and superior performance to current products.

- Repositioning: to increase the product potential market, the product is promoted for new categories of customers-for these, the product is a new product even the product essential characteristics are unchanged.

- Cost reductions: obtained by replacing the expensive materials or by process redesigning.

New product launch at global level represent a competitive advantage that global companies use to create, stimulate and increase the demand. The unknown companies never launch products at global level without the existence of that vehicle platform-based on minimum historical of the companies which reduce the risks of such launching effort.

\section{Success Factors of New Product Launch}

New products launch is an essential determinant of company performance (Blundell, Griffin, \& Reenen, 1999; Urban \& Hauser, 1993) thus, it is obvious the necessity to learn more about the factors that affect the success of new product launch. As well as it is attempted to emphasize the main success factors, it is also trying to define the term success (Hart \& Craig, 1993), which is not so easy. This aspect is a real issue because how the new product success is defined surely influences the research attempting to describe de factors which contribute to a success launch of a new product (Hart, 1993). Through extensive research, some papers succeeded to identify 
some dimensions of new product success (Cooper, 1984; Cooper \& Kleinschmidt, 1987a), but a lack in knowledge still is: one of the problems is the time perspective-no delimitation was established between short and long term of new product success, other issue is related to the firm characteristics, and also another suggestion is the necessity to measure the indicators of new product success (Griffin, 1993; Hart, 1993). In the light of this knowledge gap, Ernst \& Young established a success definition: "A new product is considered a success if it achieved at least $80 \%$ of 26 -week sales per distributing store after two years" (Mathews, 1997).

New products can bring big advantages, but not all new products succeed, therefore it arise a question "What separates the winners from losers?" It is crucial to understand the various success factors when a new product is launched (Cooper \& Kleinschmidt, 1987b) this understanding could serve as a guide about how to manage the launch of a product.

First approach of the literature review about the success factors of new products launch has based on an attempt to summarize the main drivers in an unstructured manner (Table 1).

Table 1. Factors for new product success

\begin{tabular}{ll}
\hline Success factors & Literature review \\
\hline Product differentiation through product advantage & Cooper and Kleinschmidt, 1987; Cooper, 1994; Hart and Tzokas, \\
& 2000; Rau, 2005 \\
Strong market orientation through a high level of market knowledge & Cooper and Kleinschmidt, 1987; Cooper, 1994; Gruenwald, 1997 \\
Clear and early product definition & Cooper, 1994 \\
Synergy between technology, production, and business proficiency & Cooper and Kleinschmidt, 1987 \\
Orientation on meeting the customer needs & Cooper, 1994; Soni and Cohen, 2004 \\
The market timing & Gruenwald, 1997; Soni and Cohen, 2004 \\
\hline
\end{tabular}

Source: Abdiu, D., Strandberg, M. and Stridsberg, M. (2006). Success Factors for launching a new product for microenterprises. Bachelor's Thesis in Business Administration.

Cooper and Kleinschmidt (1987) state that there are three essential factors which should be taking into account in the launch process:

- Product uniqueness-through offering to consumers a value that could not be found on existing products;

- Good market knowledge-through market analyses and extensive market research;

- Synergy between technology, production, and business proficiency.

In addition to this three factors could be also considering the importance of product differentiation (Rau, 2005). If it is considered the market evolution, Hart and Tzokas (2000) have found another three factors which are significantly correlated to the success of new product launch in growth and mature markets: the product advantage, the effort of sale force, and the distribution costs.

For companies is necessary to know the success recipe before launch the new products, thus it is important to have an early and clear product definition. Following this consideration, Cooper (1994) includes four aspects: 1) the target market; 2) the product concept and its advantage; 3) the positioning strategy; 4) the product characteristics and attributes. This approach could represent a big probability to arise the success rate of the products launch. A strong market orientation is another factor that Cooper (1994) suggested, because a better understanding of customers needs, the nature of market, and the competitive environment are essential for success, even they are often missing (Cooper, 1994; Soni \& Cohen, 2004). A new product failure can occur when the product advantages are too innovative for the targeted market. Therefore, due to this view, the market timing became essential to take into consideration (Gruenwald, 1997). The seasonal variations in requests and changes in environment turn the timing decision into an important factor for new product launch (Soni \& Cohen, 2004).

A second approach of the literature regarding successful new product launch reveals the importance of launch decisions, which could turn into essential determinants of product success. This perspective could be seeing in a structured way, as launch literature identified two categories of launch decisions-strategic and tactical (Căpătînă, 2014a; Antony \& Benedetto, 1999; Hutlink, Hart, Robben, \& Griffin, 1997).

Strategic decisions should to answer to questions such as what, where, when and why to launch a new product. These decisions are made in an incipient phase, before the product development, and in a later phase they are not easy to change and could be costly (Rubio \& Redondo, 2005). Product strategy refers to a new product that is 
closer to success if it is a really new product and owns unique characteristics. The product uniqueness is related to: success rate, profitability rate, domestic market share, and influence on the company success rate (Cooper \& Kleinschmidt, 1995). But, there are opinions according to which product uniqueness and innovativeness not last long time because of the imitated product launched by the competition. Market strategy is related to a clear understanding of the customers' needs and the importance of market nature. In recent years the pillars of new product launch consist in: a careful targeting, the competitors' avoidance, and the new products placing into growth markets (Hutlink, Hart, Robben, \& Griffin, 2000). Competitive strategy could be another determinant of product success. Unfortunately, the most new products are just brand extensions with some modifications, and they are launched in a mature market with a high competition (Adams, 1994). There are researchers which state that competitive strategy not affects so much the product success (Cooper \& Kleinschmidt, 1987), and they believe that a product could succeed mainly due to the managers' actions, and not because of the environment. Firm strategy describes the firm overview towards the launch process, for instance there are strategies based on technology or market, when it is followed cost minimization, innovation or imitation.

Tactical decisions involve the necessity to answer to the question how to launch a new product. These decisions are made after the product has been developed and the changes could be made in the ultimate phase of the development process. Product tactics are related to the branding policy and the width of product range (Hutlink et al., 2000). Branding could be a primordial mean if it is build right, and like a results of this action, it can bring benefits such as: premium price, readily placement, and high or constant outcomes (Jobber, 2001). Also, a large product line could be significant factor to increase the market share (Lambkin, 1988). Price tactics when it is about a new product should to consider a lot of elements. The product price could be an indicator of the product quality, its advantages and uniqueness. Promotion tactics have an essential role in the success of a product, because the rivals cannot be always avoid, therefore the company must to differentiate from them. It is right that promotional activities could be expensive, but they have a positive impact on the new product launch. Contrary, Debruyne, Moenart, Griffin, Hart, Hutlink and Robben (2002) suggest that an aggressive promotion could increase the competition. Distribution tactics are important in earning the consumers' confidence. The main role of distribution is to ensure the availability of new products to customers.

\section{The Case of iPhone Launch}

In this era of globalization, mobile phone industry plays a crucial role in our lives considering that almost every people use a device to communicate, to watch movies, to navigate on Internet, to take photos, to listen to music, and also to be fashionable (Katz \& Aakhus, 2002). As a consequence, a lot of companies launched smartphones to meet both local and international requests.

Apple Inc. is an innovative company operating in the sphere of multimedia and high technology. Apple activities are diverse, and that make a confused strategic line. The company was the 7 th global manufacturer before enter in the phone market in 2007. The iPhone era has begun on the 9th January 2007 when Steve Jobs presented the iPhone 2G, but the real launch was in June at The Macworld Conference where the first iPhone was showed to the public. After iPhone was successfully launched, millions of iPhones was sold, turned it in one of the most popular mobile phone ever launch. With this overwhelming success, Apple spends now its resources on diversification. The purpose of this case study is to explain how a company as Apple can enter in a saturated market-mobile phone market-and have success. In other words, this paper attempts to explain the factors that contributed to the success of iPhone launch.

Apple through the iPhone launch has fundamentally changed the established order of the handset phone industry. The rivals not treated this revolutionary launch seriously enough. One way to explain how Apple changes the phone industry is to analyse what companies were the incumbent players in 2007. For example, HTC was the first company who launched the Google Android platform as a competitive response to the iPhone. Samsung also responded to iPhone launch, and still enjoy the success as a result-the company was until recently the world largest phone producer with its Galaxy line of Android phone-inspired by the iPhone. The innovative iPhone forced other phones to raise the standards. Apple had a big success and competitions learned a lot from this revolutionary product.

This paper followed a case-study methodology (Eisenhardt, 1989; Yin, 2003), that it is a well known research method for exploratory research. Yin (2003) says that a case study is an empirical inquiry that "investigates a contemporary phenomenon within real-life context", "relies on multiple sources of evidence [...] and benefits from the prior development of theoretical propositions to guide data collection and analysis".

In an attempt to determine the factors that contributed to the success of iPhone launch, we considered an extensive literature review and Internet search, and then categorized the success drivers in order to appreciate 
how and why the iPhone launch has been a real success. It has started from the hypothesis that the iPhone launch model is one of the success reasons; therefore, it is suggested a set of factors which explain this situation.

Table 2. Success factors in iPhone launch at different levels

\begin{tabular}{lll}
\hline Level & Success factors & iPhone approach \\
\hline Consumers & Demographics & Target the right consumers \\
& Cultural & Identify and value the cultural elements \\
& Preferences & Identify and understand consumers \\
Company & Product & Different from traditional phones \\
& Price & Build relationship with customers \\
& Distribution & Changed traditional distribution \\
& Promotion & Create memorable advertising \\
Environmental & Regulatory & Working with regulatory factors \\
& Infrastructure & Exploit of existing infrastructure \\
\hline
\end{tabular}

The iPhone launch model cannot determine itself the success of the product, one of the key determinants of the success is the user acceptance. Extensive research was based on the users' reasons to accept a product, and not on the all factors that bring the product success. In order to involve all crucial drivers of product success, we attempted to summarize the findings considering three essential levels-consumers, company, and environmental (Table 2).

\subsection{IPhone Success Factors: Consumers'Level}

We start with the consumers' approach that reveals three essential drivers of successful iPhone introduction: demographics, cultural, and consumers' preferences. Demographics factors are related to the company attempting to target the right consumers, whose profile has been studied in various researches. Therefore, iPhone consumers are predominant male, aged between 25-30 years, college graduate, and high income (M:Metrics, 2008). There is a study according to which over half of iPhone consumers are under 30 years, and belonging to art, scientific, or information world, also three quarters of customers have purchased at least once Apple products. Apple has based on the iPod or iTunes experience, learned from it, and applied with success to the iPhone. Apple has reduced the price of the iPhone and undertook actions which promoted application that have involved demographics, in order to target other segments (Cauley, 2008). Also, iPhone has made a right move when focused on personal use, considering that $61 \%$ of iPhone use is for personal, while $15 \%$ is for real business use (Liao, 2008).

The success of new products launch on international markets depends on a set of factors, including a variable specific to the market-culture, which remains a significant factor in international marketing research (Căpătînă, 2014b). The iPhone has revolutionized the concept of mobile phones, and has become an icon of our modern culture and society.

The excitement surrounding the iPhone launch was not only in U.S. Apple has chosen to apply the same marketing strategies and program for Europe countries. In U.S., for a better consumers' satisfaction, it was introduced applications for $\mathrm{m}$-commerce, or entertainment applications. All applications approved by Apple gives confidence to consumers, thus the iPhone offers to users the sense of security (Dai \& Palvia, 2008). But while in western cultures the iPhone has been widely accepted, there are Asian countries that face challenges related to culture issues. For instance, in China is inappropriate to have your personal computer, and as a consequence of this fact, the young Chinese people spend their time in internet cafes. The iPhone could provide a good option in spite of all the barriers from the government. Consumers' preferences represent another important success factor of iPhone launch. It was indicated the necessity for more capabilities of mobile phones (Funk, 2000), as consumers expected a complex content, but they are reticent to pay for it. Also, consumers need mobile phones which are simple because they are not attracted of complicated devices (Venkatesh, Ramesh, \& Massey, 2003).

\subsection{IPhone Success Factors: Company's Level}

This section is about the factors that contribute to the successful iPhone launch from company perspective, particularly the marketing mix decisions-product, price, distribution, and promotion. It is very important for the company to create a successful marketing mix of the right product sold at the right price, at the right place, and with the help of the appropriate promotion. 


\subsubsection{Product Decisions}

As a device, the first iPhone was different from traditional mobile phones-it have a big touchscreen for video and Web, a browser adapted from computer standards, a customer user interface with intuitive panning and zooming, and without physical keyboard or keypad. The major limitation was that the initial iPhone did not have the 3G customary in European smartphones. The browser mainly relied on Wi-Fi access, which was common in European phones at the time, but was disable in most phone sold by U.S. network operators. Other aspects related to iPhone products are:

- Apple offered one year warranty and optional three years Apple care warranty;

- In 2008, Apple launched a cheaper version of iPhone with less but advanced characteristics, good for professional use;

- Apple provided innovative characteristics, such as: big disk storage capacity, lower weight, thinner device, 4G wireless, GPS, HD video recording-which differentiate iPhone from rivals products.

For successful iPhone branding, Apple adopted differentiation strategy-helping it to differentiate their products from competitors that resulted in a competitive advantage. The competitors such as Samsung, Nokia, HTC, or Blackberry offered multiple innovative products at a reasonable price, but cannot offer in a single device. Meanwhile, iPhone had the capability to offer many functions in a single device.

\subsubsection{Price Decisions}

In order to buy the first iPhone version, it has been stated that hundreds of people expected outside the Apple or AT\&T stores before the launch. The established price was $\$ 599$, and two months later Apple decided to reduce the price to $\$ 399$. Earlier customers have been disturbed by the lower price, and for their satisfaction, Apple decided to offer every customer who bought iPhone before reduction $\$ 100$ credit for Apple store. From this situation Apple learn that pricing should be attached more importance. Pricing strategy should not only help companies increase revenue, but also build relationship with their customers and show whether the customers are willing to purchase the products at a certain price.

\subsubsection{Distribution Decisions}

In planning where to sell the iPhone, Apple made changes in the traditional distribution channels, avoiding providers as Best Buy-a decision that could confuse customers and risk future distribution plans with those retailers who were avoided. The Apple's operator, AT\&T, provided the iPhone devices in about 1.800 company's stores; also iPhone has been available through Apple's website (Sharma \& Wingfield, 2007).

For the operators from the distribution chain the crucial measure of success for the iPhone launch was winning new customers. The reason that they allowed to share revenues with Apple was for the incremental revenues.

Table 3. First iPhone launch in European countries

\begin{tabular}{ll}
\hline Country & Details \\
\hline France & Date: November 29 2007; Operator: Orange, the subsidiary of France Telecom; Sales: 70.000 \\
& iPhones in the first month \\
& Date: November 9 2007; Operator: T-Mobile, the subsidiary of former PTT Deutsche Telekom; \\
Germany & Sales: 70.000 iPhone in the first 11 weeks \\
& Date: November 9 2007; Operator: O2, the former BT Cellnet; Sales:190.000 iPhones in the first \\
United Kingdom & two months \\
\hline
\end{tabular}

After the U.S. iPhone launch, in November 2007 Apple has launched the iPhone in the three biggest European countries using mobile phone franchises (Table 3). Another big expansion was the launching in China in October 2009 and in South Korea a month later.

\subsubsection{Promotion Decisions}

Apple has used for a long time an efficient promotion. Apple introduced its first advertising, titled Hello, for the iPhone on the Academy Award. The advertising began with a ringing phone and presented clips of different movies characters answering the phone. Even Apple has spent lesser than its competitors, the advertising became noticeable because was memorable and vibrant. During a year from launch, Apple has aired nine new TV advertising, whose goal was to reinforce the iPhone presence in media, and create to consumers an impression that it is constant present in the popular media. With iPhone launch, Apple obtained the Marketer of the Year 
award, due to the Apple's "rare accomplishment of successfully bringing a new product into an already crowded and competitive market" (Bulik \& Cuneo, 2007).

\subsection{IPhone Success Factors: Environmental Level}

Apple has worked with regulatory factors in their products launch and known a big success. A regulatory factor, that could contributes to the iPhone success or failure, is the situation when iPhone is sold locked. In Europe are countries where is not allowed the sale of locked phones. But are customers willing to buy the unlock phones version? The providers which sell iPhone in countries where are regulatory restraints, establish a higher price for unlocked devices, and a lower price when a contract is signed. There are opinions that unlocked phone may force the Apple to appeal at multiple providers to sell the iPhone in each country (Palmer, 2007). This could increase sales and market share of the iPhone. The iPhone considered the infrastructure of each country and took advantages of the unvalued areas due to the problematic infrastructure. Therefore, working with regulatory factors, companies from mobile industry could succeed.

\section{Conclusions}

Regarding the case study conclusion it can be said that iPhone changed the way that consumers interact with the mobile phones; it built a connection with the consumer and influenced their behavior regarding the information access and digital lifestyle. Considering consumers' level, Apple targeted young people and proved a predilection for personal use. Apple was centered on entertainment application in order to meet the needs of targeted consumers.

At company level, the iPhone was different from traditional mobile phones-it provided innovative characteristics. For successful iPhone branding, Apple adopted differentiation strategy-iPhone had the capability to offer many functions in a single device. From the pricing perspective, Apple followed the skimming strategy-set high prices initially in order to obtain high revenues from early customers and then prices are dropped. This pricing strategy contributed to the success of iPhone, as it has allowed the iPhone to be mass-marketed to general consumers. For the operators from the distribution chain the crucial measure of success for the iPhone launch was winning new customers. In the first year Apple introduced nine new TV advertising, whose goal was to reinforce the iPhone presence in media, and create to consumers an impression that it is constant present in the popular media.

When it is about environmental level, this study case provided two categories of drivers-regulatory and infrastructure. Apple accepted the regulatory factors, and worked with them to launch iPhone in order to achieve a high level of success. Therefore, working with regulatory factors, companies from mobile industry could succeed. The iPhone exploited the infrastructure of each country and took advantages of the unvalued areas due to the problematic infrastructure. To conclude, organization management has several essential decisions to make related to the launch of new products. To be more successful the management has to control a good mix of success factors.

\section{Acknowledgements}

This work was cofinanced from the European Social Fund through Sectoral Operational Programme Human Resources Development 2007-2013, project number POSDRU/159/1.5/S/142115. Performance and excellence in doctoral and postdoctoral research in Romanian economics science domain".

\section{References}

Abdiu, D., Strandberg, M., \& Stridsberg, M. (2006). Success Factors for launching a new product for microenterprises. Bachelor's Thesis in Business Administration. Jonkoping University, Sweden.

Adams, D. (1994). Parallel market analysis: A technique for risk-averse brand Innovation. Journal of Brand Management, 2, 221-226. http://dx.doi.org/10.1057/bm.1995.3

Antony, C., \& Benedetto, D. (1999). Identifying the Key Success Factors in New Product Launch. Journal of Product Innovation Management, 16, 530-544. http://dx.doi.org/10.1016/S0737-6782(99)00014-4

Bari, T. I. (2010). Tratat de economie politică global. Editura Economică. Bucuretti.

Becheikh, N., Landry, R., \& Armara, D. (2006). Lessons from innovation empirical studies in manufacturing sector: a systematic review of the literature from 1993-2003. Technovation, 26, 644-664. http://dx.doi.org/10.1016/j.technovation.2005.06.016

Blundell, R., Griffith, R., \& Reenen, J. (1999). Market share, market value and innovation in a panel of British manufacturing firms. Review of Economic Studies, 66, 529-554. http://dx.doi.org/10.1111/1467-937X.00097

Booz, A., \& Hamilton. (1982). New Product Management for the 1980s. New York: Booz, Allen, and Hamilton 
Inc.

Bulik, B. S., \& Cuneo, A. Z. (2007). APPLE. Advertising Age, 78, 41.

Căpătînă, G. (2014). New Product Launch: A Critical Review and Research Directions. International Journal of Economics Practices and Theories, 4(5), 607-621.

Căpătînă, G. (2014). The influence of culture on marketing programs for new products launch. SEA-Practical Application of Science, 2(3), 175-184.

Cauley, L. (2008). AT\&T: We're all about wireless. Retrieved from http://www.usatoday.com/money/industries/telecom/2008-07-31-att-iphone-stephenson-apple_N.htm.

Cooper, R. G. (1984). How new product strategies impact on performance. Journal of Product Innovation Management, 1(1), 5-18. http://dx.doi.org/10.1016/S0737-6782(84)80038-7

Cooper, R. G. (1994). New Products: The Factors that Drive Success. International Marketing Review, 11(1), 60-67. http://dx.doi.org/10.1108/02651339410057527

Cooper, R. G., \& Kleinschmidt, E. J. (1987). New products: What separates winner from losers? Journal of Product Innovation Management, 4(3), 169-184. http://dx.doi.org/10.1016/0737-6782(87)90002-6

Cooper, R. G., \& Kleinschmidt, E. J. (1987). Success factors in product innovation. Industrial Marketing Management, 16(3), 215-223. http://dx.doi.org/10.1016/0019-8501(87)90029-0

Cooper, R. G., \& Kleinschmidt, E. J. (1995). New Product Performance: Key to Success, Profitability and Cycle Time Reduction. Journal of Marketing Management, 11, 315-337. http://dx.doi.org/10.1080/0267257X.1995.9964347

Cooper. (1993). Winning at New Products: Accelerating the Process from Idea to Launch (2nd ed.). Reading, MA: Addison-Wesley.

Dai, H., \& Palvia, P. (2008). Factors Affecting Mobile Commerce Adoption: A Cross-Cultural Study in China and the United Stated. Proceedings Americans Conference on Information Systems, 1-14.

Debruyne, M., Moenaert, R., Griffin, A., Hart, S., Hutlink, E., \& Robben, H. (2002). The Impact of New Product Launch Strategies on Competitive Reaction in Industrial Markets. The Journal of Product Innovation Management, 19, 159-170. http://dx.doi.org/10.1016/S0737-6782(01)00135-7

Del Monte, A., \& Papagne, E. (2003). R\&D and growth of firms: Empirical analysis of a panel of Italian firms. Research Policy, 32, 1003-1014. http://dx.doi.org/10.1016/S0048-7333(02)00107-5

Eisenhardt, K. M. (1989). Building theories from case study research. Academy of Management Review, 14, 532-550. http://dx.doi.org/10.2307/258557

Flor, M. L., \& Otra, M. J. (2004). Identification of innovating firms through technological innovation indicators: An application to the Spanish ceramic tile industry. Research Policy, 33, 323-336. http://dx.doi.org/10.1016/j.respol.2003.09.009

Funk, J. (2000). The Mobile Internet Market: Lessons from Japan's i-mode System. Proceedings E-Business Transformation Conference.

Griffin, A. (1993). Metrics for measuring product development cycle time. Journal of Product Innovation Management, 10(2), 12-125. http://dx.doi.org/10.1016/0737-6782(93)90003-9

Gruenwald, G. (1997). How to Create Profitable New Products-from Mission to Market. Chicago: NTC Business Books.

Hart, S. (1993). Dimensions of success in new product development: An exploratory investigation. Journal of Marketing Management, 9(1), 23-41. http://dx.doi.org/10.1080/0267257X.1993.9964215

Hart, S., \& Craig, A. (1993). Dimensions of success in new product development. Perspectives on Marketing Management, 3, 207-243.

Hart, S., \& Tzokas, N. (2000). New product launch "mix" in growth and mature product markets. Benchmarking. An International Journal, 7(5), 389-405.

Hutlink, E. J., Griffin, A., Hart, S., \& Robben, H. (1997). Industrial new product launch strategies and product development performance. Journal of Product Innovation Management, 14, 243-257. http://dx.doi.org/10.1016/S0737-6782(97)00009-X

Hutlink, E. J., Hart, S., Robben, H., \& Griffin, A. (2000). Launch Decisions and New Product Success: An 
Empirical Comparison of Consumer and Industrial Products. Journal of Product Innovation Management, 17, 5-23. http://dx.doi.org/10.1016/S0737-6782(99)00027-2

Jobber, D. (2001). Principles \& Practices of Marketing (3rd ed.). Berkshire: McGraw Hill.

Katz, J. E., \& Aakhus, M. A. (2002). Perpetual contact: Mobile communication, private talk, public performance. USA: Cambridge University Press. http://dx.doi.org/10.1017/CBO9780511489471

Klette, T. J., \& Griliches, Z. (2000). Empirical patterns of firm growth and R\&D investment: A quality ladder model interpretation. The Economic Journal, 110, 363-387. http://dx.doi.org/10.1111/1468-0297.00529

Klette, T. J., \& Kortum, S. (2004). Innovating firms and aggregate innovation. Journal of Political Economy, 112, 986-1016. http://dx.doi.org/10.1086/422563

Kotler, P. (2006). Marketing Management. Bucharest: Teora.

Lambkin, M. (1988). Order of Entry and Performance in New Markets. Strategic Management Journal, 9, 127-140. http://dx.doi.org/10.1002/smj.4250090713

Lentz, R., \& Mortensen, D. T. (2005). Productivity growth and worker reallocation. International Economic Review, 46, 731-751. http://dx.doi.org/10.1111/j.1468-2354.2005.00344.x

Li, Y., \& Zhu, K. (2009). Information acquisition in new product introduction. European Journal of Operational Research. http://dx.doi.org/10.1016/j.ejor.2008.09.030

Liao, J. (2008). IPhone Usage Statistics. CNET. Retrieved from http://asia.cnet.com/blogs/infochat/post.htm?id=63004236

Loof, H., \& Heshmati, A. (2006). On the relation between innovation and performance: A sensitivity analysis. Economics of Innovation and New Technology, 15, 317-344. http://dx.doi.org/10.1080/10438590500512810

Mathews, R. (1997). Efficient New Product Introduction. Progressive Grocer, 8-12.

MiMetrics. (2008). iPhone Hype Holds Up. Retrieved from http://www.marketwire.com/press-release/M-MetricsiPhone- Hype-Holds-Up-833439.htm

Nurmi, S. (2004). Plant size, age and growth in Finnish manufacturing. Finnish Economic Papers, 17(1), 3-17.

Palmer, M. (2007). Apples phone roll-out in Europe proves tricky. Retrieved from http://www.ft.com/cms/s/0/8b26ca68-989f-11dc-8ca7-0000779fd2ac.html?nclick_check=1

Rau, S. (2005). How to build a great product. Handbook of Business Strategy, 67-72. http://dx.doi.org/10.1108/08944310510556982

Rubio, A. G., \& Redondo, Y. P. (2005). Tactical launch decisions: influence on Innovation success/failure. Journal of Product \& Brand Management, 14(1), 29-38. http://dx.doi.org/10.1108/10610420510583725

Săvoiu, G., Simăn, I., \& Crăciuneanu, V. (2012). The phenomenon of concentration-diversification in contemporary globalization. Romanian Statistical Review, 4.

Sharma, V., \& Wingfield, N. (2007). Is iPhone AT\&T's Magic Bullet? The Wall Street Journal, (15).

Soni, A., \& Cohen, H. (2004). Successfully launching your product: getting it right. Handbook of Business Strategy, 5(1), 263-268. http://dx.doi.org/10.1108/10775730410493955

Stiglitz, J. (2010). În cădere liberă America, piața liberă şi prăbuşirea economiei mondiale. Bucureşti: Editura Publica.

Stoenescu, R. D. (2014). Stereotypes in consumers' product evaluation based on the country-of-origin. $S E A-$ Practical Application of Science, 3(5), 623-630.

Thompson, P. (2001). The microeconomics of an R\&D based model of engenous growth. Journal of Economic Growth, 6, 263-283. http://dx.doi.org/10.1023/A:1012761811439

Urban, G. L., \& Hauser, J. R. (1993). Design and Marketing of New Products (2nd ed.). NJ: Prentice Hall.

Venkatesh, V., Ramesh, V., \& Massey, A. (2003). Understanding Usability in Mobile Commerce. Communications of the ACM, 46(12), 53-56. http://dx.doi.org/10.1145/953460.953488

Wallace, T. (2014). Top Ecommerce News You Need To Know; Highlights from Apple, PayPal, Facebook. Retrieved from http://blog.bigcommerce.com/ecommerce-news-10-12-14/

Yang, C. H., \& Huang, C. H. (2005). R\&D, size and firm growth in Taiwan's electronics industry. Small Business 
Economics, 25, 477-487. http://dx.doi.org/10.1007/s11187-004-6487-7

Yin, R. K. (1989). Case Study Research: Design and Methods. London: Sage.

\section{Copyrights}

Copyright for this article is retained by the author(s), with first publication rights granted to the journal.

This is an open-access article distributed under the terms and conditions of the Creative Commons Attribution license (http://creativecommons.org/licenses/by/3.0/). 